\title{
Strategies of Literary Translation
}

\author{
Tamara A. Kazakova* \\ St. Petersburg State University \\ 7/9 Universitetskaya nab., St. Petersburg, 199034, Russia
}

Received 28.08.2015, received in revised form 18.09.2015, accepted 17.10.2015

Literary translation includes a wide range of activities that deal not only with fiction or poetry but also with popular science essays, newspaper articles, diaries, memoirs, etc. These different kinds of texts presuppose different strategies and criteria of translation processing. The unified approach is to consider them integrally as nonstrictly determined translation opposed to strictly determined documentary translation. The difference between the two manifests itself mainly in the proportion of overt and covert regulations and criteria for the choice of equivalents. Literary translation is a covertly regulated process, which is connected with a number of complications, i.e. personal nature of texts under translation (authorship); unspecified audience; interlingual and intercultural inequality; and some others. The lack of systemic criteria determines the use of intuitive choices, such as observer-, helper-or enlightener-strategy.

Keywords: literary translation, covertly regulated translation, interlingual inequality, measure of authorship, biased and unbiased strategies, types of literary information.

DOI: 10.17516/1997-1370-2015-8-12-2842-2847.

Research area: philology.

\section{Introduction}

Much has been written and said about literary translation, yet the term is mainly applied to translating fiction (poetry and prose). Meanwhile, fiction is but a moderate part of the great amount of texts that require bilingual literary processing. Every translator knows well the difference between processing a poem or a literary diary, although it will make difficulty to verbalize this difference. In practice, we consider them as different types of text to be perceived and translated, even if they use similar words and sentence structures. Usually and, mostly, aposteriori, we argue about such vague features as stylistic (pragmatic, communicative, etc.) adequacy, imagery, aesthetic or cultural acceptability, verisimilitude and apply a diversity of other criteria to the assessment of a translated text. From my own experience, I know that two independent critics may evaluate a translated poem (or any other literary work) with relatively or fundamentally opposite conclusions. These considerations have made me work on a sort of model for literary translation strategy. To be reasonable, I try to stand to the informational principle (Razumovskaya, 2014; Kazakova, 2011, 2015) in measuring the translation process.

(c) Siberian Federal University. All rights reserved

* Corresponding author E-mail address: tamakaza@gmail.com 


\section{The status of literary translation}

There is a widely spread conviction that literary translation is 'free' as opposed to documentary translation that is 'exact'. The conviction is none but delusion, a common misconception, which, to a certain extent, has been generated by critics and translatologists who persuade us that literary translation is 'an art' whereas documentary translation is 'a craft' (nowadays, they use the term 'industry', yet more technical and impersonal). I think, the opposition has always been somewhat artificial since art is but an advanced degree of craft and as such requires even greater adherence to strict norms and strategies. The misconception has been further developed in the arguments of theoreticians and translators themselves about style (literary quality) of the text as something external towards meaning.

I think, the delusion is due to the concept of meaning, of what we mean when we say something, e.g. 'rabbit' (Quine, 1976). What we mean when we write something in the form of a poem - or a note in the diary - or a newspaper article? In fact, this hypothetical meaning consists of many meanings, some of which are very far from the dictionary or common grammar and are perceived (or not) and interpreted (or not) in human processing the text as information. From this point of view, meaning is information, that is, an impact of the text on our senses, which does not concern only reason but also feelings, imagination, experiences. To stir up those areas, the text may be straight and simple or vague and intricate; unpretentious or sophisticated and the impact will vary depending on the parlance and the receiver.

In this attitude, the literary work differs from the documentary text by its informational capacity. A document appeals to reason and is intended for logical perception as a clear-cut subject matter. To avoid entropy as much as possible, its informational capacity is limited to the purport, which is why the parlance is strictly determined to be unambiguously perceived. The level of determination and, accordingly, the restrictions of ambiguity may differ in different cultures and require different linguistic means to follow the purport but the samples are considered equivalent irrespective of the language. What is required from the documentary translation is the steady knowledge of such samples in the appropriate areas.

A literary work appeals to both sense and sensations and is meant to trouble them, to produce the regulated entropy, i.e. catharsis. Therefore, its informational capacity is the more unlimited the greater the ability of the author to trouble the reader. The hyperinformativity of such texts require special means of expression, from rhythm and rhyme to allusions and citations. The informational nature of the literary parlance requires, on the one part, the necessity of regulated translation, yet on the other part, the covert character of literary information predetermines covert regulations. By covert regulations I mean nonstrictly determined rules of equivalence that will involve an intensive informational search. Thus, literary translation may be defined as a special type of bilingual revision of a literary text, which involves many kinds of processing, from comparative natural language processing to knowledge processing.

\section{Types of literary information}

Literary information is a capability of a literary text to correlate with senses of the reader (translator) through such levels of information as lingual standards and associative thoughts and emotions conditioned within a certain probable context. Two basic types of literary information are objective and subjective. Let us consider them more closely. 
Objective information is the impact of the text on the reader conditioned by the standard collective use of the language, i.e. linguistic information (Piotrowsky, 2006) and knowledge, i.e. ecumenic information (Cherniakhovskaya, 2009;). It includes linguistic information (style, lexicon and grammar), cultural (social-historical) information, and subject area information. In standard perception, part of these informational components may be lost, e.g., the level of the style, vocabulary or grammar exceeds the linguistic competence of the reader - then the text becomes informationally overburdened and, although objective, the information does not make for the proper impact, which often happens with poetry (sophisticated style), refined essays (sophisticated grammar) or popular science (sophisticated special vocabulary). The objectivity of information does not necessarily make for its intelligibility to all probable readers and all kinds of deviation and/or distortion are always possible. It is especially true as to the translator whose linguistic and cultural competence usually differs (though is not inevitably inferior to) from that of the native audience to whom the author addresses his message and whose response (Nida, 1964) is expected.

Subjective information is the impact of the text on the reader conditioned by the author's personal implication (it may not coincide with the standard associations and meanings) as well as by the reader's personal experience and imagination. The author may prefer (or detest) particular words, names or events but will not manifest his preferences or detestations in verbal forms (e.g. "I detest hyacinth"); the signs and signals for such information are hints, allusions, situations (e.g. a negative personage permanently uses "the hyacinth scent", etc.). Subjective informational components usually refer to emotive, expressive or evaluative meanings and form the so-called 'subtext'. The major problem with this information is that the positions of the author and the reader about this or that particular preference will not coincide and may even oppose each other. Supposing, the reader loves hyacinth (see the example above)? In this case, the author's "negative message" will be lost on him; more than that, the entropy will spread and the positive attitude will transfer to the 'personage with hyacinth' and thus distort the author's covert message. Nor less intricate are personal symbols that require intensive analytical processing of not only the particular text but also the whole corpus of the author's works.

Special remarks should be made concerning non-fiction literary texts. There is a widely spread attitude towards them as to the texts of mostly (if not absolutely) objective, i.e. logically structured information. Yet current practices show that more kinds of non-fiction contain many components introducing personal judgements rather than logically proved concepts or ideas. Importantly, such judgements refer to the personal style and manner of the author not less than to the intention to influence the reader, to persuade or dissuade him, to share some special experiences andlor emotions through the probable impact. Such components, informative as they are, fulfill a more significant function of a potential impact on the attitudes of the reader. These features become a particular problem when either their verbal carriers do not functionally coincide in the source and target language or judgements themselves do not meet the appropriate reaction, e.g. domestic and foreign perception of a particular event or phenomenon may differ fundamentally, in which case the emotive/evaluative message of the author is distorted or lost. With the fiction (poetry or prose) it may be important but not crucial whereas with non-fiction literary texts the lost or distorted emotive information may shift or replace not only the emphasis 
but also the concept or idea themselves, i.e. the logical meaning of the message. Thus, we should consider such stylistic elements not as ornamental but also (sometimes even basically) essential for the structure of meaning.

These preliminary considerations are closely connected with the idea of a variety of strategies required for translation of different kinds of literary texts to provide the appropriate informational impact on the reader.

\section{Types of literary translation strategies}

Dealing with a diversity of literary texts and sophisticated structures of information, the translator needs effective strategies of bilingual information processing. A closer view at current literary translation strategies shows certain models and techniques used by translators to compensate the inevitable or supposed losses of information. Such strategies are mostly intuitive, both biased and unbiased. When coming across serious unregulated complications, the translator tends either to protect the reader against them or to let him survive in deep waters. By unregulated complications, I mean objective obstacles, e.g. interlingual or intercultural inequality, etc., and subjective obstacles, e.g. interpersonal discrepancies, implications and expectations, etc.

Unbiased principles as means to retain more verbal characteristics of the source text manifest themselves as observer-strategy and/or adherent-strategy. The observer-strategy shows such features as the impersonality of choices and indifference to the supposed reader; translating fiction through such strategy, the translator usually tends to neutralize stylistic peculiarities of the source text, especially the author's personal preferences; there is also much evidence of the standard equivalents offered by the bilingual dictionary even if such equivalents provide only formal equality but fail to transfer functional equality of the counterposed linguistic units. The adherent-strategy shows even more conservative principles and enhances the tendency towards the transfer the original verbal forms as they are; culturally-determined words (the so-called realia) are transliterated while grammatical forms and structures, e.g. the order of words, are transferred without transformation though, sometimes, breaking the norms of the target language.

The utter product of such strategies is the literal translation, which may represent the verbal form of the original but with disastrous effects for the implicit informational components, i.e. all kinds of the subjective information. In case of translating non-fiction, such strategies may seem more appropriate though nor less disastrous when the source text is strongly marked by the author's idiolect; such are the problems with translating diaries, memoirs, speeches of the outstanding public figures, and popular science. It often happens that the translator has no choice when it comes to the inequality of the inner form of terms: the term comprehensible to the wide audience of the source text due to its clear semantics becomes sophisticated and accessible only to specialists. If such terms appear in the specialist-oriented article, the unbiased strategy is appropriate; if it concerns the popular science, such an approach may cause a serious complication for the nonspecialist reader - the intended audience. For example, such is the dilemma in translating the term lander: for the English reader the meaning of the word is clear and associative to people who are not technicians as something that lands (the moon lander, Mars lander, etc.) on the surface. Translated into Russian, it invariably becomes взлетно-посадочный модуль and thus loses its associative power, estranging the text from the non-specialist. When such terms are many in a text, the translated popular science becomes very technical and unintelligible to the non-specialist audience. 
Biased strategies tend to protect the reader from the interlingual and intercultural complications (helper-strategy) or to educate him providing additional information and extending the text in translation (enlightener-strategy). Following the helper-strategy, the translator uses more analogues or descriptions rather than transliterations (in the case of realia); he also tends to make the syntax of the translated text more comfortable for the reader; he may even withdraw some units or formulations from the text if they seem to him unintelligible or too specific. The most unwelcome interference of such a helpertranslator into the impact of the text on the reader is the change of emotive or evaluative colouring of the information, just in case the reader will not suffer the troublesome interpretation. The enlightener-strategy manifests itself, first, through an amount of notes and comments; the enlightener-translator is, as it were, sure that the reader does not know or does not want to refer to dictionaries or other sources of information. Sometimes this strategy is productive when the literary, historical or cultural resonance of the translated work is significant or unpredictable. One of such literary phenomena of immense cultural resonance is Master and Margarita by
Michael Bulgakov. The nine English translation variants of the book develop an obvious trend from the helper to the enlightener-strategy: from Michel Glenny (1967) to Michael Karpelson (2010), every new translator enlarges a serious commentary; Glenny's translation had none of comments or notes (and is most convenient in the readers' collective opinion) whereas the next translation variants successively open more and more sophisticated aspects of the text by means of the translator comments.

\section{Conclusion}

Literary translation is a covertly regulated process marked by a number of complications: the personal nature of texts under translation (authorship); unspecified target audience; interlingual and/or intercultural inequality; and some others. Intuitive strategies recognized in literary translation practices include observerstrategy, helper-strategy and enlightener-strategy as attempts to deal with the complications. Systemic structuring of such complications in their interdependence with the informational features of the text may help to work out a useful theoretical model for identifying a reasonable translation strategy.

\section{References}

Cherniakhowskaya, L. (2009). Informational approach to translation [Informatsionny podhod k perevodu]. Mir perevoda, 22.

Piotrowsky, R.G. Linguistic synergetics: initial positions, preliminary results, perspectives [Lingvisticheskaya synergetika: iskhodniye polozheniya, perviye rezultaty, perspektivy]. St. Petersburg, 2006.

Kazakova, T. Propositions on Current Trends in Russian Translation Studies. Translation Theories in the Slavic Countries. Salerno, Europa Orientalis, 2015.

Kazakova, T. Translation as Processing Information. Fedorov Readings XI. St. Petersburg, 2011.

Nida, E.A. (1978). The Setting of Communication: a Largely Overlooked Factor in Translation Babel, 24, 3-4.

Quine, W.V.O. Word and Object. Cambridge, 1960.

Razumovskaya, V. A. (2014). Self-Translation as Science-Art: Joseph Brodsky Legacy. J. of Siberian Federal University. Humanities and Social Sciences, 7(2), 294-304. 


\title{
Стратегии литературного перевода
}

\section{Т.А. Казакова}

Санкт-Петербургский государственный университет Россия, 199034, Санкт-Петербург,

Университетская наб., 11

\begin{abstract}
Литературный перевод представляет собой широкий круг деятельности, охватыввая не только перевод художественной литературы (поэзии и прозы), но и научно-популярной литературы, очерков, газетныхматериалов, дневников, мемуаров ит.п. Различные виды текстов, требуюших литературной обработки, вызывают необходимость различных переводческих стратегий и критериев перевода. Эти различия в целом сводимы к понятию нестрого регламентированного перевода в противоположность строго регламентированному переводу документов. Разнииа между ними проявляется преимущественно в соотношении очевидных и неочевидных правил и критериев выбора эквивалентов. Литературный перевод определяется неочевидными правилами, что диктуется иельмм рядом осложнений, в частности, индивидуальностью авторства, неопределенностью аудитории, межъязыковыми и межкультурными различиями и т.д. Отсутствие системы критериев предопределяет интуитивный поиск соответствий, выражаясь в таких формах, как стратегия отчуждения, помощчи или просветительства.
\end{abstract}

Ключевые слова: литературный перевод, нестрого регламентированный перевод, межъязыковые различия, оченка авторства, пристрастные и беспристрастные стратегии, типь литературной информации.

Научная специальность: 10.00.00 - филологические науки. 